\title{
The Grenada Revolution: Investigating the Ambitions and Shortcomings of a Radical Caribbean Political Experiment
}

\author{
Shenhat Haile 2T1 \\ University of Toronto \\ FAS History, Political Science \& African Studies
}

\section{A B S T R A C T}

In March 1979, the New Jewel Movement (NJM) transitioned into the People's Revolutionary Government (PRG) through a bloodless coup that for a time revolutionized the structure of governments in the Common-law Caribbean. This policy review seeks to consider the success of the revolution based on: its aim of developing and sustaining a grassroots democracy, emphasis on mass education and its expansion of agribusiness initiatives as a part of broader industrialization efforts. Through an investigation of some of the critical events, ideological frameworks and ambitious political objectives that briefly transformed Grenadian society from 1979 to 1983 this review illustrates the complexity of the political experiment undertaken by the People's Revolutionary Government and argues that despite its short time span, the Grenada Revolution remains one of the most critical examples of revolutionary potential and

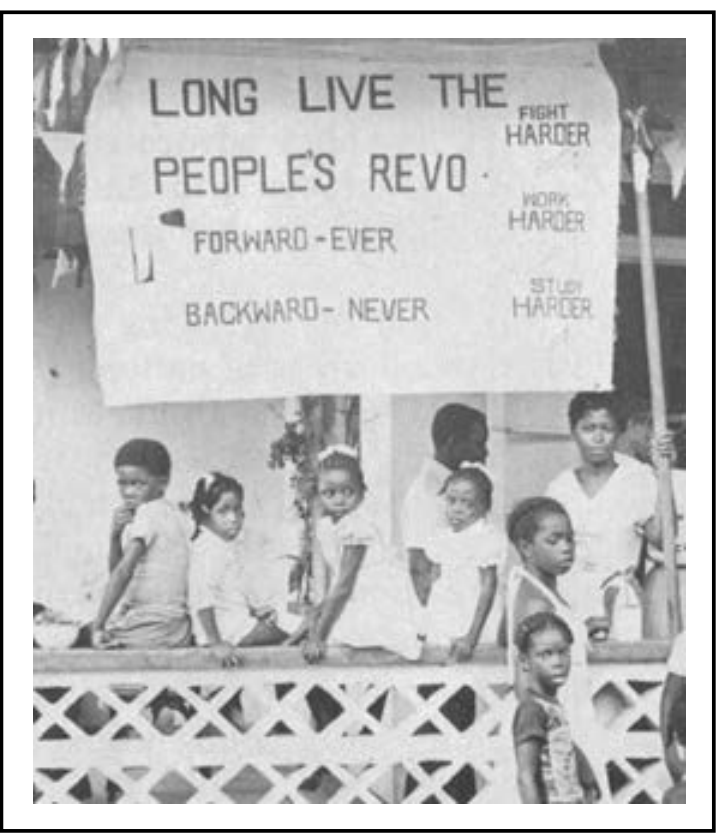

Keywords: Grenada Revolution, People's Revolutionary Government, New Jewel Movement, Maurice Bishop radical self-rule in the twentieth-century Caribbean.

\section{B I O}

Shenhat has a BA from the University of Toronto with a double major in History and Political Science and a minor in African Studies. Her academic interests include history and politics of the Horn of African, anti-/alternative development theory, and intellectual histories of Caribbean decolonization and transnational Black radical feminism.

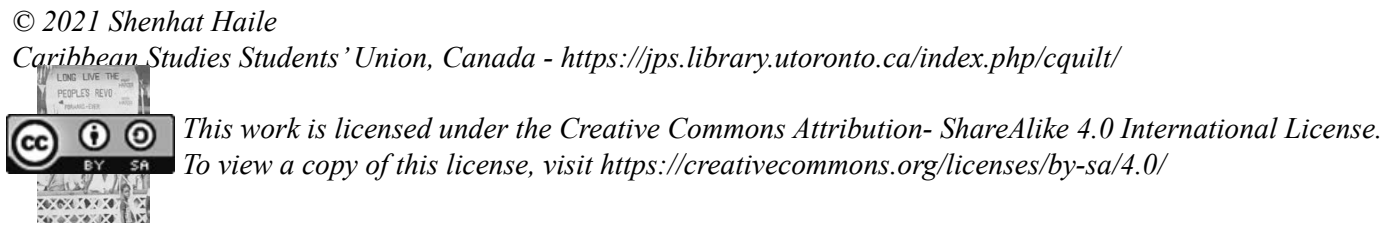


On the 13th of March, 1979, a bloodless coup transformed the trajectory of political and social development on the island of Grenada. This policy review will investigate some of the critical events, ideological frameworks, and ambitious political objectives that briefly transformed Grenadian society from 1979 to 1983 . The Grenada Revolution is regarded as one of the very few successful political experiments undertaken by a leftist vanguard party and arguably epitomizes the revolutionary potential of the organized Caribbean masses. Thinking alongside this notion, this review seeks to critically analyze the policy decisions of the People's Revolutionary Government (PRG), considering the revolution's aim of developing a grassroots democracy, emphasis on mass education reform, and the expansion of agribusiness initiatives as a part of broader industrialization efforts.

To understand the peaceful ousting that took place on 13 March 1979, we must first briefly recall the administrative abuses, political corruption, and general public contempt that characterized Eric Gairy's government that would give rise to6 revolutionary opposition led by Maurice Bishop and The New Jewel Movement (NJM). While he enjoyed general popularity in the early period of Grenada's independence ${ }^{2}$, evidence of Gairy's political abuse was made apparent as early as 1962. . Gairy's attempts to consolidate greater executive powers would subsequently lead to the detrimental findings of the Commission of Inquiry, the suspension of the constitution, and the call of new elections in $1962 .^{4}$ Gairy returned to popularity five years later in the 1967 election through a "demagogic 'Land for the Landless' programme" that put him back in credible position against the opposition however Gairy never followed through with the land redistribution initiative and once again lost the faith of the planter class. ${ }^{5}$ Gairy continued to use extralegal means to consolidate full Cabinet authority, silencing his critics, and developing both an overt system of political patronage and a violent personal paramilitary, the seeds of revolutionary opposition had been planted. ${ }^{6}$ Widespread discontent towards Gairy's abuse of power surged across Grenada. Meanwhile, a new radical organization was being formed that would confront Eric Gairy's despotism.

In 1973, the Joint Endeavour for Welfare, Education and Liberation (JEWEL) led by Unison Whiteman and Maurice Bishop's Movement for Assemblies of the People (MAP) joined together to form the Marxist-Leninist oriented, New Jewel Movement. 'According to Bishop, this "was an unconventional type organization," in the sense that electoral politics was not its primary objective. ${ }^{8}$ Instead, it intended to weaken Eric Gairy's support base, raise the political consciousness, and advocate

\footnotetext{
${ }^{1}$ Kate Quinn, "Conventional Politics or Revolution: Black Power and the Radical Challenge to the Westminster Model in the Caribbean," Commonwealth \& Comparative Politics 53, no. 1 (February 2015): 73.

2 Anne Hickling Hudson, "Education in the Grenada Revolution: 1979-83," Compare 19, no. 2 (1989): 96.

3 Quinn, 73.

${ }^{4}$ Brian Meeks, Caribbean Revolutions and Revolutionary Theory: an Assessment of Cuba, Nicaragua and Grenada

(Kingston: Univ. of the West Indies Press, 2001): 140.

5 Meeks, 140.

${ }^{6}$ Quinn, 73.

7 The Black Scholar, "Revolution in Grenada: An Interview with Maurice Bishop,” Journal of Black Studies and Research 11, no. 3 (1980): 52.

${ }^{8}$ Ibid. 
for new transparent structures of government. ${ }^{9}$ The NJM grew its political base by organizing with agricultural workers who were facing economic distress, attracting middle-class conservatives who were frustrated with the corruption of the current government, and by promoting a model of democracy in which genuine political participation was encouraged and deemed necessary for development. ${ }^{10}$ According to Kate Quinn, the bloodless coup of 1979 was thus "so [easy] partly because the ideological groundwork for the revolution had already been laid." 11 Many of the strengths of the political experiment in Grenada can be identified in the first few years following the formation of the PRG government (led by NJM members and Bishop as Prime Minister), where revolutionary spirits were high and people's political participation was in full force. ${ }^{12}$ While there could certainly be a much more robust conversation on the progressive policy decisions made during the PRG's leadership, I will limit my analysis to the following matters: the development of grassroots democracy, an emphasis on mass education reform, and the expansion of agribusiness initiatives and industrialization efforts.

As mentioned, many scholars attribute the early success of the revolution to the enthusiastic willingness of Grenadians across all social classes. ${ }^{13}$ Maurice Bishop and the PRG were determined to address the poor socio-economic conditions left behind by colonial structures and the post-independence government by tackling the source of these problems. The vision was to move past the neo-colonial model of Westminster exclusionary electoral politics into a form of "grassroots democracy" that operated on the voluntary mobilization of ordinary Grenadians. ${ }^{14}$ The PRG was especially able to foster a real sense of camaraderie, dignity and self-determination in the youth by giving them leadership positions within the party. ${ }^{15}$ The PRG was also comprised of town and village residents, leading figures of the private business class, trade unionists, and anyone "who had allied themselves with the NJM's nationalist profile and analysis of reforms necessary to bring about development." ${ }^{15}$ The most important features of this new grassroots democracy were the new organizations created to ensure wide scale political participation at the local level. For instance, the National Youth Organization, the National Women's Organization, and the Productive Farmer's Union each had thousands of members contributing to different economic and social projects. ${ }^{17}$ In addition to this were a number of village, parish and workplace assemblies that would have direct representation in the National Assembly. ${ }^{18}$ This was essentially a direct alternative to the former two-party Westminster system that was structurally incapable of responding to the people's

\footnotetext{
${ }^{9}$ Ibid.

${ }^{10}$ Quinn, 76.

11 Quinn, 72.

${ }^{12}$ Gail R. Pool, "Culture, Language and Revolution in Grenada," Anthropologica 36, no. 1 (1994): 82.

13 Hudson, 97.

${ }^{14}$ Revolution in Grenada: An Interview with Maurice Bishop," 56.

15 Pool, 87.

${ }^{16}$ Hudson, 97.

${ }^{17}$ Hudson, 98.

18 Quinn, 82.
} 
needs. ${ }^{19}$ In situating power across regions of the country and stimulating support through public meetings and mass rallies, the PRG was able to secure what was believed to be long-term support for the revolutionary government. ${ }^{20}$

Alongside raising the political morale of the people, the PRG government allocated considerable time, effort and investment into transforming Grenada's education system. The legacy of colonial education was identified early on as major obstacle to rolling out the government's bold plans for social and economic development. ${ }^{21}$ Prior to the revolution, the school system was characterized by high illiteracy rates, underachievement, and generally poor academic performance.22 Foremost efforts at addressing this dysfunction were directed towards adequate professional training for teachers and educators, resulting in the establishment of a community-based program called the Centre for Popular Education in $1980 .^{23}$ Reforms were later made to eliminate school fees, expand school capacities, prioritize university education programmes that were functional to the needs of a developing society, encourage skills development, and produce a more socially-conscious student and worker. ${ }^{24}$ The goal was to gradually develop an education system that would feed the needs of a rapidly diversifying and industrializing Grenada.

Lastly, development and GDP growth in Grenada was to be pursued through a mixed economy. ${ }^{25}$ In the colonial period, Grenada was primarily a sugar economy that gradually came to include nutmeg, cocoa and bananas. ${ }^{26}$ One of the main objectives of the PRG was to increase the processing capacity of these essential industries, while also expanding public-sector enterprises. ${ }^{27}$ Anne Hickling-Hudson describes the PRG approach to economic development as "flexible, gradualist and pragmatic." ${ }^{28}$ Its policies sought to deal with the issue of import substitution by commercializing surplus fruits into canned products, expanding farmer cooperatives, and investing in the local fishing industry. ${ }^{29}$ The biggest impact to Grenada's economy was arguably the trade agreements and foreign assistance supplied by other socialist states which allowed the PRG to further invest in the public sector and create thousands of new jobs. ${ }^{30}$ Public-sector ownership grew to become 30 per cent of the economy and by 1983 the unemployment rate dropped by well over fifty per cent of the Gairy administration's 1978 levels. ${ }^{31}$ According to Maurice Bishop, the economic objective was for Grenada to "not live in anyone's backyard." ${ }^{32}$ Despite allowing the still dominant private sector to preserve its ties

${ }^{19}$ Ibid.

20 Ibid., 75.

${ }^{21}$ Hudson, 96.

22 Ibid., 101.

23 Ibid., 109.

24 Ibid., 104.

25 Hudson, 99.

26 Pool 82.

27 Hudson, 99.

28 Ibid.

${ }^{29}$ Ibid.

30 Ibid.

31 Ibid.

32 "Revolution in Grenada: An Interview with Maurice Bishop," 58. 
with Western investors, it is clear that the PRG's long-term goals for Grenada were centred around the principles of self-sustainability and the rejection of foreign ownership.

It is in these progressive policies undertaken during the brief leadership of the People's Revolutionary Government that we can see the opportunities and possibilities that were left unfulfilled. For instance, the ambitious education reform plan was designed to ensure that certain vocational programs were prioritized in a sequential manner. ${ }^{33}$ Upon the discussion and deliberation of community members and teachers, the shifting needs of education would be reconsidered and the Ministry of Education would progress into the next stage of development. ${ }^{34}$ There were also plans put in place in 1983 to seek collaboration with Cuban officials on how to develop and expand a sophisticated work-study program for students going into the agricultural industry. ${ }^{35}$ According to Hudson, the PRG emphasized the need for long-term education reform because: "By 1982, it was clear that without such education, progress would be severely constrained in the many new projects in construction, in the hotel industry, in craft design, in food technology, in scientific agriculture, forestry and fishing, in economic and environment planning, and in financial and administrative management.", 36
Despite the tremendously progressive and impactful achievements of the PRG, many opportunities for further growth were cut short due to the downfall of the revolution in 1983. Before addressing the major weaknesses of the PRG's policy decisions, it is important to consider the domestic and international forces that threatened the survival of the revolutionary government. While it was Bishop's desire to pursue a general policy of non-alignment, the nature of the political objectives and the government's revolutionary ideology of anti-imperialism and self-determination naturally led the PRG to align itself with Cuba and other members of the socialist bloc. The March 1979 coup, growing affiliations with Cuba, and the state's new stance against foreign ownership and Western intervention made Grenada a target of US suspicion. Anxiety towards a socialist spread or European alliance in the Caribbean had been of much concern to the United States even before the enactment of the Monroe Doctrine in 1823. As Brian Meeks puts it:

"Grenada's significance went far beyond its importance as a micro-state, because it was the first revolution carried out by Black English-speakers, with direct lines of communication to the major black and West Indian population centers in North America and Great Britain and because it presented the US for the first time since the Vietnamese War with an opportunity to reassert its hegemonic tendencies "37

\footnotetext{
${ }^{33}$ Hudson, 102.

34 Ibid., 103.

35 Ibid., 105.

${ }^{36}$ Ibid., 99.

${ }^{37}$ Rupert Roopnaraine, “Resonances of Revolution: Grenada, Suriname, Guyana,” Interventions 12, no. 1 (2010): pp. 11-34.

38 Quinn, 82.

39 Meeks, 160.
} 
In a similar way, Kate Quinn describes the PRG's political experiments as "the most radical deviation from the Westminster model ever attempted in the Commonwealth Caribbean." 38 In a region so heavily dominated by capitalist modes of development and neo-colonial exploitation, Grenada was providing the ideological foundation and revolutionary praxis to refashion the relationship between Caribbean states and hegemonic powers. This anxiety towards Grenada's pursuit of alternative development was heightened by the PRG's plans to build an airport on the island. Additionally, though the revolution sparked an unprecedented level of political mobilization, the small minority of remaining Gairy loyalists who did not see themselves represented by the new government may have proved to be a major threat to the survival of the revolution in the near future. ${ }^{40}$ However, the internal conflict that would contribute to the downfall of the government did not occur between the PRG and this minority, but amongst the leading members of the revolution itself. It is widely understood that the crisis of 1983 that put an end to the revolution was the result of a quiet opposition faction within the party led by Minister of Finance Bernard Coard. ${ }^{41}$ On the other hand, scholars argue that this narrative of conspiracy often shifts attention away from other factors that played a role in the ultimate collapse of the PRG. ${ }^{42}$ It is therefore very critical to consider some of these threats when discussing the major flaws and weaknesses of the revolutionary experiment in Grenada.

According to Brian Meeks, author of Caribbean Revolutions and Revolutionary Theory (1993), "The failure of most studies to explore the relationship between actors and structures is a fatal error." ${ }^{43} \mathrm{He}$ argues that many of the political objectives laid out by Bishop and the PRG were appropriate for Grenada's development, but experienced difficulty in execution. This is in large part due to the "clandestine vanguard structure" of the party and the way in which power was seized and socialist policy was pursued from a "paternalistic" approach. ${ }^{44}$ For instance, Meeks argues that in gaining the support of the masses, populist leaders like Maurice Bishop are able to present the idea of national elections as an unnecessary and counter-productive activity that could ultimately undermine the revolutionary party. He also cites that the PRG's refusal to hold elections contradicted the party's aims to genuinely involve the population in a grassroots democracy movement ${ }^{45}$ and signalled more distress towards an already alert United States. Additionally, the seemingly impressive developmental growth during 1979 and 1983 is often attributed to the large sums of loans and foreign aid provided to Grenada from it socialist links, not from a sudden influx of economic activity on the island. ${ }^{46}$ The funnelling of this aid into public industries meant that private sector performance

\footnotetext{
${ }^{40}$ Meeks, 161.

${ }^{41}$ Ibid., 131.

42 Ibid., 132.

${ }^{43}$ Ibid.

${ }^{44}$ Ibid., 160.

45 Ibid.

46 Meeks, 164

47 Ibid.

48 Ibid.

${ }^{49}$ Ibid., iii.
} 
suffered during these few years. ${ }^{47}$ Efforts to diversify the economy from agribusiness to tourism did not make significant changes and the majority of the country's export was still dependent on the staple crops - nutmeg, cocoa and banana. ${ }^{48}$ Meeks therefore concludes that the revolutionary party was in economic crisis long before it "finally succumbed to internal dissension" in 1983 . $^{49}$ The PRG's fall would leave the country vulnerable to US invasion shortly thereafter.

In this policy review, I have attempt to illustrate the complexity of the political experiment undertaken by the People's Revolutionary Government from 1979 to 1983. Despite its short time span, the Grenada Revolution arguably remains one of the most critical examples of revolutionary potential and radical self-rule in the twentieth-century Caribbean. The strengths and weaknesses of this political experiment indicate the difficulty revolutionary socialist governments face when attempting to distance themselves outside the reach of Western imperialist forces. 


\section{Works Cited}

Hudson, Anne Hickling. "Education in the Grenada Revolution: 1979-83." Compare 19, no. 2 (1989): 95-114.

Meeks, Brian. Caribbean Revolutions and Revolutionary Theory: an Assessment of Cuba, Nicaragua and Grenada. Kingston: Univ. of the West Indies Press, 2001.

Pool, Gail R. "Culture, Language and Revolution in Grenada." Anthropologica 36, no. 1 (1994): 73-107.

Quinn, Kate. "Conventional Politics or Revolution: Black Power and the Radical Challenge to the Westminster Model in the Caribbean." Commonwealth \& Comparative Politics 53, no. 1 (2015): 71-94.

Roopnaraine, Rupert. "Resonances of Revolution: Grenada, Suriname, Guyana." interventions 12, no. 1 (2010): 11-34.

The Black Scholar. "Revolution in Grenada: An Interview with Maurice Bishop." Journal of Black Studies and Research 11, no. 3 (1980): 50-58. 